\title{
ANALYZING SPATIAL AND TEMPORAL VARIABILITY OF SOIL WATER CONTENT $\left({ }^{1}\right)$
}

\author{
SIDNEY ROSA VIEIRA $\left({ }^{2}\right)$; CÉLIA REGINA GREGO $\left({ }^{3}\right)$; GEORGE CLARKE TOPP $\left({ }^{4}\right)$
}

\begin{abstract}
During the last two decades geoestatistical methods have been intensively used for in-depth descriptions of spatial variability. The objective of this study was to assess the spatial and temporal variability of soil water content. The measurements were taken with a TDR equipment to a $20 \mathrm{~cm}$ depth, in a nearly flat 1.2 ha field at the Central Experimental Farm of the Agriculture Canada, Ottawa. The soil classified as a Rideau soil series, is a clay loam soil. A square grid with $10 \mathrm{~m}$ spacing was laid out, resulting in 164 sampling points at which two TDR rods were installed to measure the water content down to $20 \mathrm{~cm}$ depth. Measurements were taken on 33 dates during the frost free months in 1987, 1988 and 1989. The spatial variability was analyzed examining the scaled semivariograms, the statistical parameters and the parameters of the models fit to individual semivariograms as a function of time. It was concluded that spatial dependence decreases as the soil gets drier and that results from one year connect almost continuously to other years. The topography and structure of topsoil horizon was the primary cause for the repeating spatial pattern of soil water content in successive samplings. The places where the mean value occurred in the field were more stable in time when there was spatial dependence. As the soil gets dryer the temporal stability of the spatial distribution tends to disappear due to the hydraulic conductivity controlling the water evaporation over the field.
\end{abstract}

Key words: TDR, temporal stability, semivariogram, geostatistics.

\section{RESUMO}

\section{ANÁLISE DA VARIABILIDADE ESPACIAL E TEMPORAL DO TEOR DE ÁGUA DO SOLO}

Durante as ultimas duas décadas métodos geoestatísticos têm sido intensamente adotados para descrever a variabilidade espacial em profundidade. O objetivo deste estudo foi avaliar a variabilidade espacial e temporal do teor de água do solo. As medições foram feitas com TDR a $20 \mathrm{~cm}$ de profundidade, em uma área plana de 1,2 ha no Centro Experimental do Ministério da Agricultura do Canadá, Ottawa, no solo de textura francoargilosa. Fez-se um quadriculado com pontos distanciados em $10 \mathrm{~m}$, resultando em 164 pontos de amostragem, nos quais duas hastes do TDR foram instaladas para medir a umidade. As medições foram realizadas em 33 datas durante os meses livres de gelo na superfície do solo em 1987, 1988 e 1989. A variabilidade espacial foi analisada através de semivariogramas escalonados, de parâmetros estatísticos e de parâmetros de ajuste de modelos para os semivariogramas individuais em função do tempo. Concluiu-se que a dependência espacial diminuiu conforme o solo tornou-se seco e os resultados de um ano conectam-se quase que continuamente com os dos outros anos. A topografia e a estrutura do horizonte superficial tiveram influência na repetição temporal do padrão de distribuição espacial do teor de água do solo. Os locais no campo onde o valor médio ocorreu tiveram maior estabilidade no tempo quando não existiu dependência espacial. Na medida em que o solo seca e a condutividade hidráulica passa a controlar a perda de água para a atmosfera, a estabilidade temporal da ocorrência de valores médios em determinados locais tende a desaparecer.

Palavras-chave: TDR, estabilidade temporal, semivariograma, geoestatística.

( $\left.{ }^{1}\right)$ Received for publication in March 24, 2006 and accepted in October 18, 2007.

$\left({ }^{2}\right)$ Centro de Pesquisa e Desenvolvimento de Solos e Recursos Ambientais, IAC, Caixa Postal 28, 13012-970 Campinas (SP). E-mail: sidney@iac.sp.gov.br $\left(^{*}\right)$ Correspondent author.

$\left({ }^{3}\right)$ Centro Nacional de Pesquisa de Monitoramento por Satélite, Embrapa, Av. Soldado Passarinho, 303, Fazenda Chapadão, 13070-115 Campinas (SP). E-mail: crgrego@cnpm.embrapa.br

$\left({ }^{4}\right)$ Eastern Cereal \& Oilseed Research Centre, Agriculture \& Agri-Food Canada, 960 Carling Avenue, Ottawa, Canada, K1A 0C6. E-mail: toppc@agr.gc.ca 


\section{INTRODUCTION}

During the last two decades geoestatistical methods have been intensively used for in-depth descriptions of spatial variability (BURGESS and WEBSTER, 1980; VIEIRA et al., 1981; NielSEN et al., 1983; VIEIRA et al., 1983; Vieira, 2000; Vieira et al., 2002). Some researchers used autocorrelograms (WEBSTER and CUANALO, 1975), others semivariograms and kriging estimation (VIEIRA et al., 1981; VIEIRA ET AL., 1983), and another ones cokriging estimation (VAUCLINE et al., 1983). Kriged contour or three-dimensional maps are popular representations of spatial variability results (HajRasuliha et al., 1980; Burgess and Webster, 1980; MacBratney et al., 1982; Vauclin et al., 1983) and provide quantitative assessments of variability.

Variability in time, and in particular, with repeating patterns is being a challenge to soil research. VACHAUD et al. (1985) showed that time stability of the spatial variability may exist for water content measured on the same locations at different times. Scaling semivariograms of several variables measured over the same field provides a simple but powerful integration method (VIEIRA et al., 1988, VIEIRA et al., 1991; VIEIRA et al., 1997) in the sense that the more the semivariograms scale the more similar the variability of the corresponding variables are. Therefore, if semivariograms scale it indicates that not only the mean values and dispersion coefficients occur at the same locations but all variability repeats in time, although the absolute values may be different. Besides, the analysis of the parameters of the models fitted to the semivariograms as a function of the time of successive samplings may be of help in assessing the temporal stability of the spatial variability.

The objective of this study was to assess the spatial variability as well as the temporal stability of spatial distribution for soil water content.

\section{MATERIAL AND METHODS}

\section{Theory}

The experimental semivariogram, $\gamma(h)$, of $n$ spatial observations $z\left(x_{i}\right), i=1, \ldots, n$, can be estimated using:

$$
\gamma(h)=\frac{1}{2 N(h)} \sum_{i=1}^{N(h)}\left[z\left(x_{i}\right)-z\left(x_{i}+h\right)\right]^{2}
$$

where $\mathrm{N}(\mathrm{h})$ is the number of pairs of observations separated by a distance $h$. Experimental semivariograms need to be fitted to some mathematical model which must meet the criteria of conditional positive definiteness (MAcBRATNEy et AL., 1982). Amongst all the variety of models which satisfy that condition, the fitting parameters that describe them are: the nugget effect $C_{0}$, the sill $\left(C_{0}+C_{1}\right)\left(C_{1}\right.$ is the structured variance coefficient to be defined later), and the range of spatial dependence $a$.

With the objective of comparing the variability of different samplings, VIEIRA ET AL. (1997) proposed a scaling technique for the semivariogram expressed by:

$$
\gamma^{s c}(h)=\gamma_{l}(h) / \alpha_{l} \quad l=1,2, \ldots, m
$$

where $m$ indicates the number of measured variables. The scale factor $\alpha$, is a constant that can take the value of the calculated variance, of the sill when it exists, of the square of the mean values or of the highest value of the semivariogram $\gamma(\mathrm{h})$. The scaling concept proposed by VIEIRA ET AL. (1997) may be helpful in the analysis of the temporal stability of the spatial variability of soil water content corresponding to different sampling dates for the same location. Within each data set (year of sampling) the scaled semivariograms for all sampling dates can be plotted together in order to make comparisons and verify if and when the spatial variability looses temporal stability. When data of several dates coalesce into a unified semivariogram structure, it is possible to take advantage of variables having the same spatial structure and, hence, reduce the number of semivariograms needed to analyze and draw interpretations regarding their spatial values.

When the semivariogram of any particular variable does not stabilize at constant value for the sill, it is an indication that the sill does not exist, and therefore, the stationarity of the mean cannot be guaranteed because the variable increases unlimitedly in some direction. In this situation, it is necessary to remove the trend before any geostatistical application based on the intrinsic hypothesis is made (VIEIRA, 2000). One possible way of removing the trend from a data set is using a trend surface fit to the data through minimized squared deviations of the difference between the surface and the original data, producing a new residual variable (VIEIRA, 2000). Trend surfaces are polynomials of some degree, usually first (linear), second (parabolic) or third (cubic), depending on which fits better the data. In this study, all soil water content data showed some trend that was best fit to a parabolic surface, $\left(Z_{e s t}\right)$, using the equation:

$$
Z_{e s t}(x, y)=A_{0}+A_{1} * x+A_{2} * y+A_{3} * x^{2}+A_{4} * x * y+A_{5} * y^{2}
$$


where $A_{0}, A_{1}, A_{2}, A_{3}, A_{4}$ and $A_{5}$ are the parameters fit. The residual variable, $\left(Z_{r e s}\right)$, can be obtained by subtracting the estimated trend surface from the original values for each point:

$$
Z_{\text {res }}(x, y) \quad Z(x, y) \quad Z_{\text {est }}(x, y)
$$

where the variable $Z_{\text {res }}$ is subsequently tested for the existence of a defined sill in the semivariogram. The kriging estimation is done on the residual values to which the estimated surface is added after the estimation is done.

As the semivariograms for the original data showed a very strong trend violating the intrinsic hypothesis of geostatistics (Journel and HuiJBregts, 1978), parabolic trend surface equations were fitted to the data and subtracted from them. The residuals generated by the difference between originals and trend surface produced semivariograms that showed a very well defined sill, and for this reason the residuals were used in the remaining analysis.

Once the semivariogram has a defined sill, a model must be fit to its experimental values in order to provide a continuous function over the whole distance range. The spherical model was fit to all semivariograms in this study, using trial and error technique and jack knifing procedure for validation (VIEIRA, 2000). The equation for the spherical model is:

$$
\begin{array}{ll}
\gamma(h)=C_{0}+C_{1}\left[\frac{3}{2} \frac{h}{a}-\frac{1}{2}\left(\frac{h}{a}\right)^{3}\right] & \text { for } h \leq a \\
\gamma(h)=C_{0}+C_{1} & \text { for } h \succ a
\end{array}
$$

Where $C_{0}, C_{1}$ and $a$ are, respectively, the nugget effect, the structured variance contribution and the range. The quantity $\mathrm{C}_{0}+\mathrm{C}_{1}$ is the sill of the semivariogram. Comparison of the semivariogram parameters for different dates of sampling is a way of supporting or not the changes in spatial variability with time. The dependence ratio (DR) defined by CAMBARDELLA ET AL. (1994) quantities the relationship between $\mathrm{C} 0$ and $\mathrm{C} 1$. The dependence ratio measures the dependence degree of a variable and is calculated by:

$$
D R=\frac{100 \times C_{0}}{C_{0}+C_{1}}
$$

Two facts are very important about the above theoretical concepts: i) The semivariogram $\gamma(\mathrm{h})$ is assumed to be isotropic, i.e., either there is no significant anisotropy or there is a transformation to remove the anisotropy before scaling is applied; ii) $\gamma(\mathrm{h})$ can take the value of the calculated variance $\operatorname{Var}(\mathrm{z})$ no matter whether it represents the true variance or not, since the scaling factor is simply a number chosen to make the semivariograms coalesce into a single curve. The reason why scaled semivariograms may provide an adequate way to analyze temporal evolution of the spatial variability is that it will be noticeable when the spatial variability pattern changes, and thus the possible cause can be examined. Therefore, scaling is used in this paper only for the comparison between semivariograms for different samplings on the same field.

\section{Data sets}

One hundred and sixty four TDR (time domain reflectometry) rods were installed in a Rideau clay loam soil in the Central Experimental Farm of Agriculture Canada, Ottawa, for measuring volumetric water content of the surface $0.2 \mathrm{~m}$ of soil. Therefore, soil water content measurements could be obtained on the same points as many times as wanted since the TDR rods remained in-place at the same points in the field. The triangular field, kept vegetated with natural pasture grass, measured $110 \mathrm{~m}$ in the $\mathrm{x}$-direction (base) and $220 \mathrm{~m}$ in the $\mathrm{y}$-direction (height), was divided into a $10 \times 10 \mathrm{~m}$ grid, as shown in figure 1a. All water content measurements over the field were collected within a two-hour time period. The topographic map of the study area is shown in figure $1 b$.
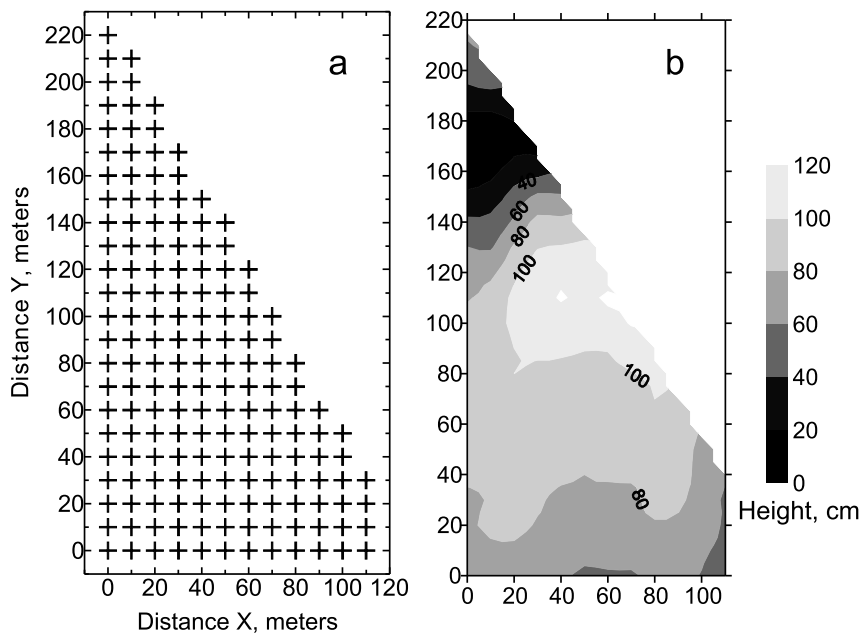

Figure 1. Studied field settings: a) Sampling scheme; b) Topography.

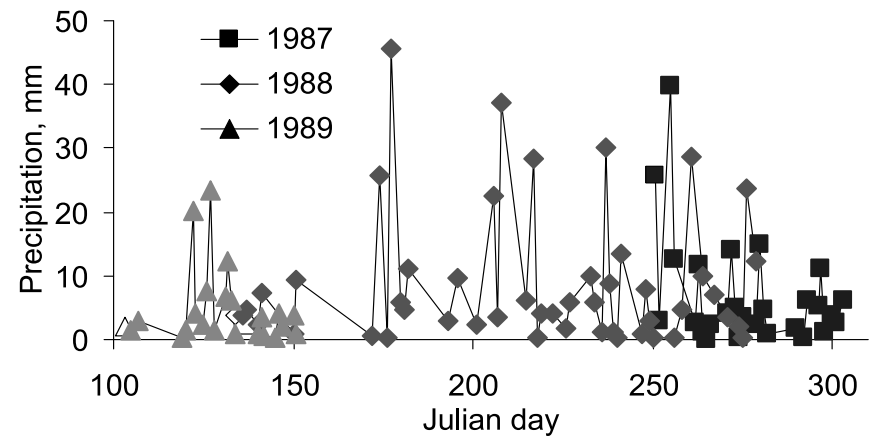

Figure 2. Rainfall as a function of time during the years. 
The study period extended from early September of 1987 until early May 1989 during the ground surface frost-free months. The dates of samplings in 1987 were September 11, 14, 17, 21, 24, and October 29 with two samplings on the same day with different TDR instruments.

There were 21 samplings dates in 1988: May 06, 13 and 30, June 06, 13, 21 and 27, July 04, 15, 22 and 28, August 11, 18 and 25, September 02, 08, 15, 22 and 29, and October 06. The dates of samplings in 1989 were April 14, 18, 21, 25 and 28 and May 01. Figure 2 shows the precipitation in $\mathrm{mm}$, during the study period.

The sampling dates were transformed in Julian days in order to make the graphs of the parameters as a function of time during the year.

The examination of the spatial variability for soil water content as the time during the year progresses may reveal information about some water content threshold value at which the soil hydraulic conductivity begins to cause changes in the spatial variability patterns.

\section{RESULTS AND DISCUSSION}

Figure 3 shows the general behaviour of the water content changes and the main descriptive statistical moments as a function of the dates of sampling. Data corresponding to September and October (end of the frost-free period of 1987, and from April and May (beginning of the frost-free period of 1989 season as the result show continuity of the statistcal parameters from one year to the other. The data from 1989 had a similar pattern to those at the beginning of 1988 and the data from 1987 had similar pattern to those at the end of 1988. These qualitative similarities indicate continuity of water content patterns from one year to the next. The mean soil water contents shown in figure 3a vary up and down about $35 \%$. Being highest at the first ground frost-free day, the soil water content then starts decreasing until a big rain occurs. Proportionally the $\mathrm{CV}$ values increase at the same times (Figure 3b), as it is noticeable from a sudden decrease in $\mathrm{CV}$ values around julian day 180, following a large rain (Figure 2). The skewness coefficients (Figure 3c), except for one date in 1987, are all slightly negative. The coefficients of kurtosis, on the other hand, are all close to 3 (Figure 3d). Therefore, it is easy to see that most of the data analyzed approach the normal distribution. From figures $3 \mathrm{e}$ and $3 \mathrm{f}$ it seems that the minimum values (Figure 3e) are more sensitive to the rainfall variation in time than the maximum values (figure 3f).
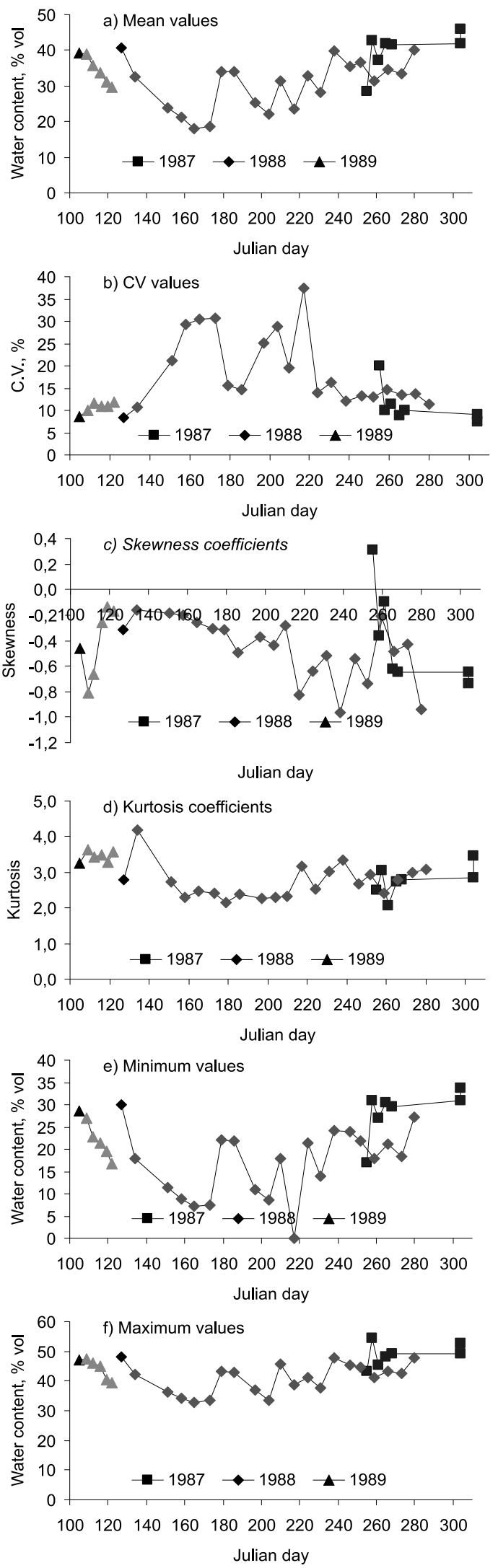

Figure 3. Statistical parameters as a function of time during the years: a) Mean values; b) CV values; c) Skewness coefficients; d) Kurtosis coefficients; e) Minimum values; f) Maximum values. 
It is possible too that for low water content values the TDR method fails to work properly as the contact between the wave-guides and the soil may become limiting in soil of a clay loam texture.

Soil water contents at this site in Ottawa showed similar sets of semivariograms for all dates for the three years (Figure 4). It can be seen that the scaled semivariograms coalesced without much scatter. All semivariograms are for residuals of parabolic trend. Although the soil map for this field is not available, there was a region located about mid way close to the diagonal side which showed probably a sandier surface texture. This region is also where the highest elevation occurs, as shown in figure $1 \mathrm{~b}$. These two factors are undoubtedly the cause for the similarity in spatial variability in different sampling dates. In general, semivariograms show that all dates sampled have strong spatial dependence to about 40 $\mathrm{m}$. This distance for spatial dependence may also result from the location of the higher elevation in relation to the shape and length of the field.
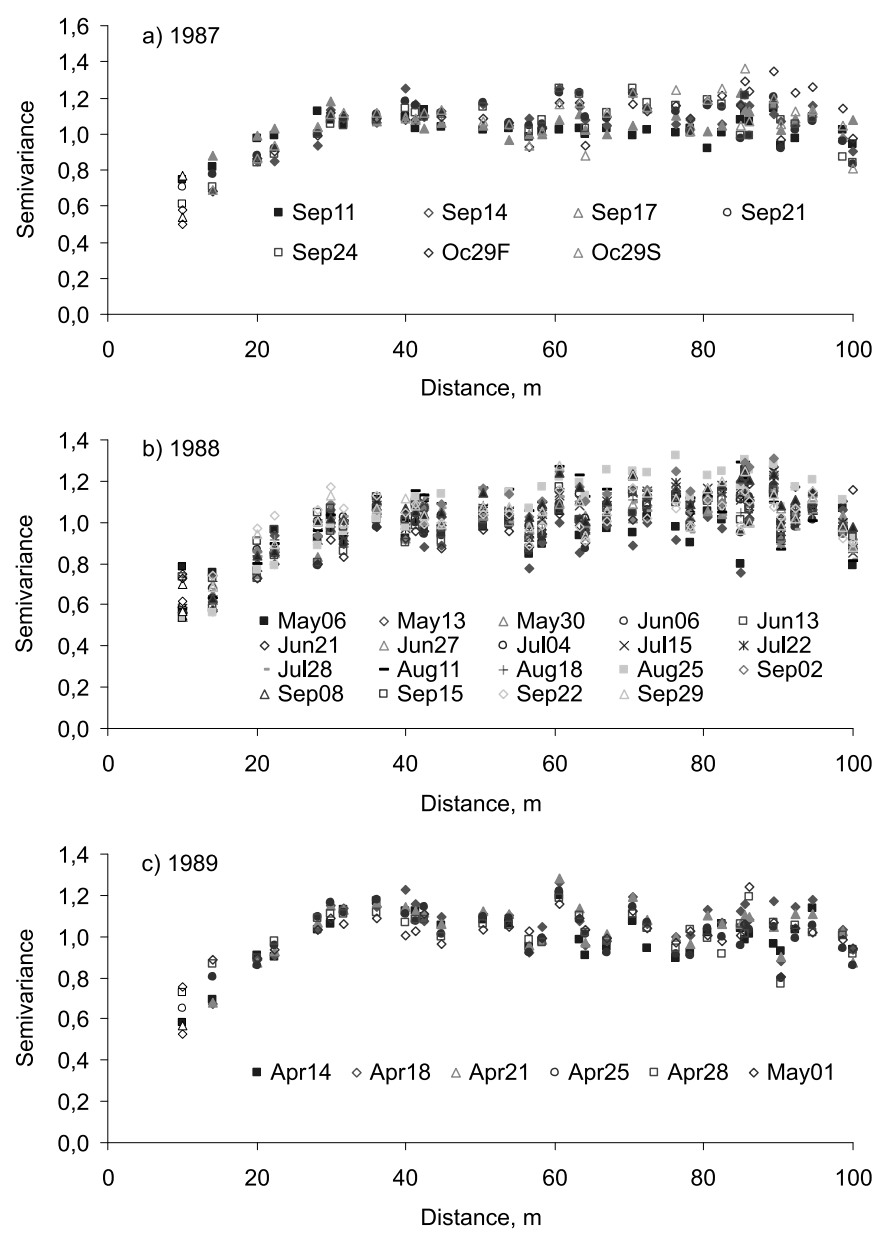

Figura 4. Scaled semivariograms for water content values: a) 1987 ; b) 1988 ; c) 1989 .
The qualitative seasonal similarity of the mean water content noted above is confirmed quantitatively by the repeated and continuous similarity of the semivariogram parameters (Figure 5). Overall, the days that showed larger ranges of spatial dependence also had higher nugget effect values as the dependence ratio indicates.
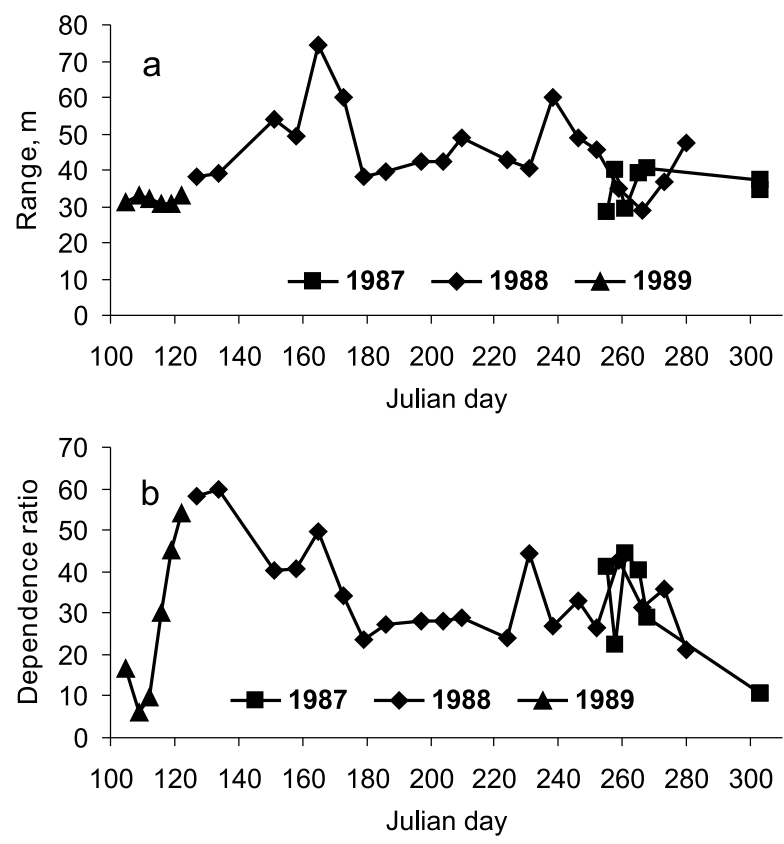

Figura 5. Semivariograms parameters as function of sampling time: a) Ranges; b) Dependence ratios.

Figure 6 shows the linear relationship between mean values and dependence ratio and between skewness coefficients and dependence ratio. These two graphs were constructed because the results indicate that they may contribute to show that the spatial variability of soil water content is stable in time within some limits of threshold value. Although this threshold value may vary from one soil to another, it seems quite evident that it does exist. The Dependence Ratio (DR) decreases linearly as the mean soil water content increases (Figure 6a). The reason for it is that as the soil water content decreases, the spatial variability of topsoil characteristics such as texture implies a different soil water content spatial distribution pattern, probably arising from the water content of coarser textured region(s) decreasing more rapidly than those of the more clayey region(s). Because the soil has not been cultivated for a long time, the variability expressed here is natural to the soil characteristics and relatively stable in time. 


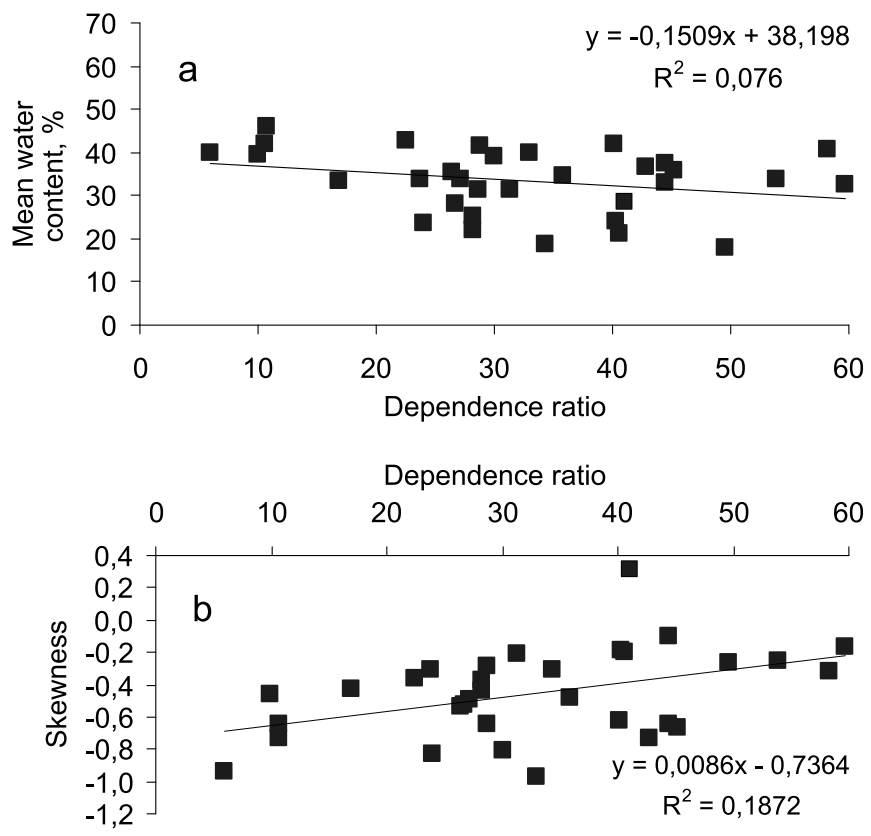

Figura 6. Relationship between statistical parameters and dependence ratio: a) Mean and b) Skewness coefficient of soil water content.

Because this soil unit has a very well developed blocky structured top soil (about $30 \mathrm{~cm}$ ), and a massive layer with no structure at deeper horizons, its hydraulic conductivity is much higher at the surface horizon than at deeper depths, according to the results reported by VIEIRA ET AL. (1988).

The skewness of the soil water content also changes proportionally to the continuity of the spatial variability (Figure 6b). Therefore, the unique condition implied by both the topography and the soil structure favors faster loss of water from the soil at higher elevation region resulting in the picture pattern expressed by the parameters shown in figure 6 . As the soil gets dryer the temporal stability of the spatial distribution tends to disappear due to the hydraulic conductivity controlling the water evaporation over the field.

As the soil water content for all dates presented parabolic trend, the parabolic trend surface parameters of equation (3) were plotted as a function of the date of sampling. The results are shown in figure 7 . The $A_{0}$ values shown in figure 7 a are very closely related to the mean soil water content. On the other hand, the $A_{1}$ and $A_{2}$ values, respectively shown in figures $7 b$ and $7 c$, indicate that the variability in the $X$ and $Y$ directions is stronger at beginning of the season than in the summer time.

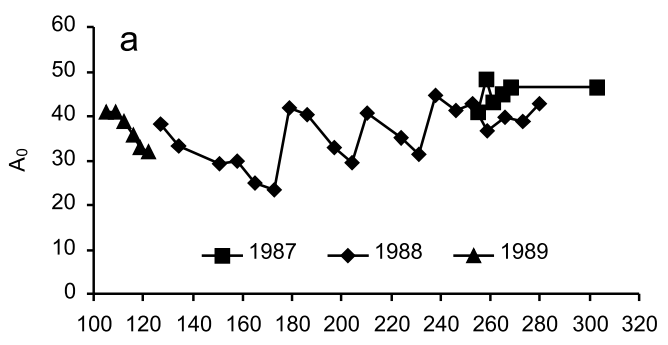

Julian day

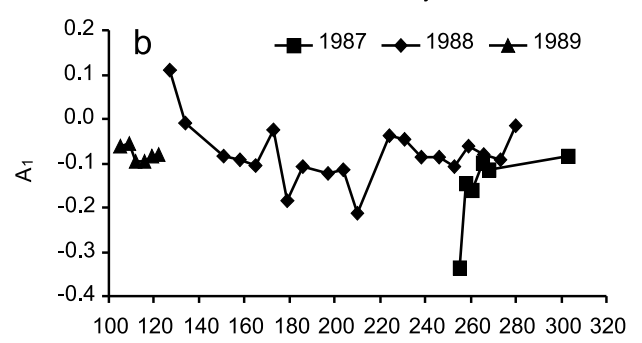

Julian day

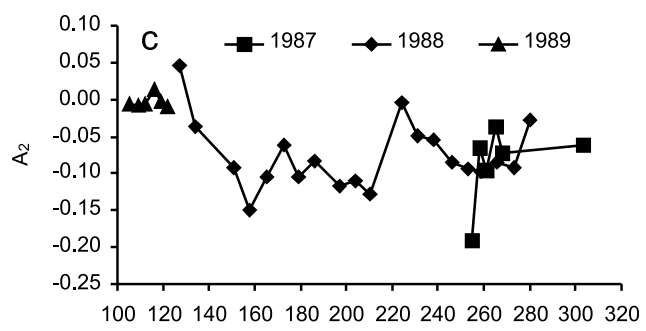

Julian day
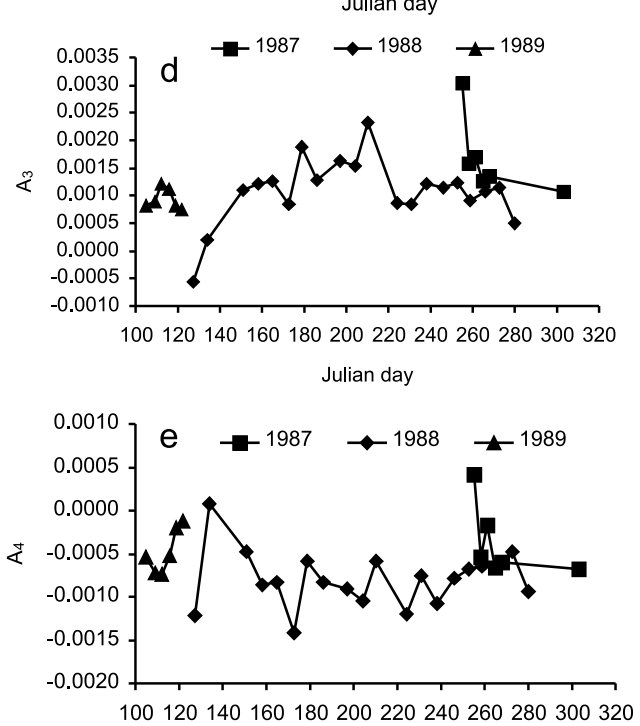

Julian day

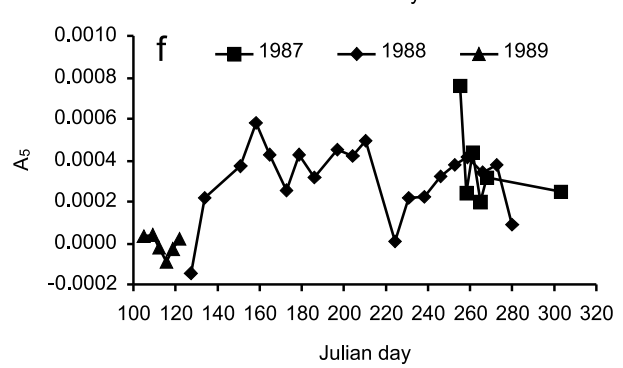

Figura 7. Parameter $A$ for parabolic trend surface used to remove trend: a) $A_{0}$; b) $A_{1}$; c) $A_{2}$; d) $A_{3}$; e) $A_{4}$;f) $A_{5}$. 


\section{CONCLUSIONS}

1. Spatial dependence decreases as the soil gets drier, and results from one year connect almost continuously to other years. As the soil gets dryer the temporal stability of the spatial distribution tends to disappear due to the hydraulic conductivity controlling the water evaporation over the field.

2. The field shows strong parabolic trend and spatial pattern of soil water content repeating in time.

3. The topographical heights are identified as being responsible for the parabolic trend and for the time stability of the spatial pattern for soil water content.

\section{ACKNOWLEDGEMENTS}

The first author wants to acknowledge Conselho Nacional de Desenvolvimento Científico e Tecnológico (CNPq) for the bilateral agreement grant provided for this work.

\section{REFERENCES}

BURGESS, T.M.; WEBSTER, R. Optimal interpolation and isarithmic mapping of soil properties. I. The semivariogram and punctual kriging. Soil Science of America Journal, Madison, v. 31, p. 315-331, 1980.

CAMBARDELLA, C.A.;MOOMAN, T.B.;NOVAK, J.M.;PARKIN, T.B.; KARLEM, D.L.; TURVO, R.F.; KONOPA, A.E. Field scale variability of soil properties in central Iowa soil. Soil Science of America Journal, Madison, v.47, p.1501-1511, 1994.

HAJRASULIHA, S.; BANIABBASSI, N.; METTHEY, J.; NIELSEN, D.R. Spatial variability of soil sampling for salinity studies in southwest Iran. Irrigation Science, Heidelberg, v.1, p.197-208, 1980

JOURNEL, A.G.; HUIJBREGTS, CH. J. Mining Geoestatistics. London: Academic Press, 1978. 600p.

MacBRATNEY, A.B.; WEBSTER R.; McLAREN, R.G.; SPIERS, R.E.B. Regional variation of extractable copper and cobalt in the topsoil of southwest Scotland. Agronomie, Paris, v. 2, n. 10, p. 969-982, 1982.

NIELSEN, D.R.; TILLOTSON, P.M.; VIEIRA, S.R. Analyzing field-measured soil-water properties. Agricultural Water Management, Amsterdam, v. 6, p. 93-109, 1983.

TOPP, G.C.; DAVIS, J.L. Measurement of soil water content using time domain reflectometry (TDR): a field evaluation. Soil Science of America Journal, Madison, v.49, p. 574582, 1985.
VACHAUD, G.; PASSERAT, S. A.; BALABANIS, P.; VAUCLIN, M. Temporal stability of spatially measured soil water probability density function. Soil Science of America Journal, Madison, v. 49, p. 822-827, 1985.

VAUCLIN, M.; VIEIRA, S.R.; VACHAUD, G.; NIELSEN, D.R. The use of cokriging with limited field soil observation. Soil Science of America Journal, Madison, v. 47, p. 175-184, 1983.

VIEIRA, S.R. Geoestatística em estudos de variabilidade espacial do solo. In: NOVAIS, R.F.; ALVAREZ, V.H.; SCHAEFER, G.R. (Ed.). Tópicos em Ciência do solo. Viçosa: Sociedade Brasileira de Ciência do solo, v.1, 2000. p. 1-54.

VIEIRA, S.R.; NIELSEN, D.R.; BIGGAR, J.W.; TILLOTSON, P.M. The Scaling of semivariograms and the kriging estimation. Revista Brasileira de Ciencia do Solo, Campinas, v.21, n. 2, p.521-533, 1997.

VIEIRA, S.R.; HATFIELD, J.L.; NIELSEN, D.R.; BIGGAR, J.W. Geoestatistical theory and application to variability of some agronomical properties. Hilgardia, Oakland, v. 51,n. 3, p. 175, 1983.

VIEIRA, S.R.; LOMBARDI NETO, F.; BURROWS; I.T. Mapeamento das chuvas máximas prováveis para o Estado de São Paulo. Revista Brasileira de Ciencia do Solo, Campinas, v.15, n. 2, p.219-224, 1991.

VIEIRA, S.R.; MILLETE, J.; TOPP, G.C.; REYNOLDS, W.D. Handbook for geostatistical analysis of variability in soil and climate data. In: ALVAREZ, V. V.H.; SCHAEFER, C.E.G.R.; BARROS, N.F.; MELLO, J.W.V.; COSTA, L.M. (Ed). Tópicos em Ciência do Solo. Viçosa: Sociedade Brasileira de Ciência do solo, v.2, 2002. p. 1-45.

VIEIRA, S.R.; NIELSEN, D.R.; BIGGAR, J.W. Spatial variability of field-measured infiltration rate. Soil Science of America Journal, Madison, v. 45, p. 1040-1048, 1981.

VIEIRA, S.R.; REYNOLDS, W.D.; TOPP, G.C. Spatial variability of hydraulic properties in a highly structured clay soil. In: WIERENGA, P.J.; BACHELET, D. (Ed.). SYMPOSIUM VALIDATION OF FLOW AND TRANSPORT MODELS FOR THE UNSATURATED ZONE, 1988. Proceedings... Las Cruces, NM: Department of Agronomy and Horticulture; Ruidoso: New Mexico State University, New Mexico, 1988. p.471-483.

WEBSTER, R.;. CUANALO, H.E. de la C. Soil transects of correlograms of north Oxfordshire and their interpretation. . Soil Science of America Journal, Madison, v.26, n. 2. p. 176194, 1975. 